\title{
Usage of Social Networking Sites: Interpersonal Communication Motives of Youth
}

Saima Zareen* , Arshad Ali and Muhammad Ali Junjua

Department of Communication Studies and Media Center, University of Gujrat, Pakistan

*Corresponding author: Dr. Saima Zareen, Department of Communication Studies and Media Center, University of Gujrat, Pakistan, Tel: +374 10 23-72-61; E-mail: zareensaima@yahoo.com

Received date: September 11, 2014, Accepted date: September 27, 2014, Published date: October 10, 2014

Copyright: () 2014 Zareen S, et al. This is an open-access article distributed under the terms of the Creative Commons Attribution License, which permits unrestricted use, distribution, and reproduction in any medium, provided the original author and source are credited.

\begin{abstract}
The study was conducted at the university of Gujrat to examine the role of social media specially facebook is creating awareness among students about political system of Pakistan and possible change in political behavior of students after exposure to political content on facebook. Survey research method was adopted in this research. A pilot study was conducted before choosing sample. During pilot study survey method was used to find out that student of which departments of University use facebook the most. It was found that students of CS/IT and MCM department use facebook. Through Survey Research, data was collected from 120 respondents, among which 67 were male while remaining 53 were female. A clear majority of $65 \%$ of the respondents belong to age group from $22-24$ years. $30 \%, 19-21.56 .7 \%$ of respondents belongs to Urban area, 30\% from Sub Urban area while only $13.3 \%$ belong to Rural area.
\end{abstract}

Keywords: Media; Communication; Society development; Political behavior

\section{Introduction}

Media has a powerful and significant role in human life. It is the source of information, entertainment and education.

Role of media in the life of people and in the society development can't be overlooked. Media is considered as the mirror of society. It has now become an important pillar of society as well as state.

Media is considered as the most influential tool of communication. Its duty is to promote the right thing on right time. A new kind of media, social media, has become an important phenomenon around the globe. It has got immense importance after its effective role in 2008 Presidential elections of U.S and its role in Arab Upspring. This study will examine the role of social media specially facebook in creating awareness among students about political system of Pakistan and possible change in political behavior of students after exposure to political content on facebook. Social network sites started emerging in 1990s and now become an important online tool. Social networks through social networking sites provides a platform to its users to communicate with each other and share personal information, beliefs thoughts, experiences, knowledge ,interest and affiliations. It also allows the users to form their online communities. Social networking sites allow users to present themselves in the form of text, videos and multimedia content. Social media includes cell phone and worldwide web bases technologies which give birth to interactive online communities. Andreas Kaplan and Michael Haenlich [1-5] defines social media as a group of Internet based application that build on ideological and technological foundations of Web 2.0 and that allows creation and exchange of user generated content.

Less than two years ago, disillusioned investors were fleeing Facebook Inc. stock, worried the company would never figure out how to make the leap to mobile devices from personal computers, let alone make money on them. Now, more than half of the giant social network's advertising revenue is coming from ads for its 1.2 billion users on smartphones and tablets. And it's buying WhatsApp after outbidding rival Google Inc. for the most popular mobile app for sending messages on smartphones.

\section{Objectives of the Research}

The objectives of this thesis are:

- To calculate relationship between online political participation and facebook usage.

- To find out the relationship between facebook usage and traditional political participation.

- To investigate the effects of online political participation on social media and traditional political participation.

- To evaluate the change in attitude of students after exposure to political content on facebook

- To find out the level of change in behavior of students after exposed to political content on facebook

\section{Significance of the Study}

Present era is the age of internet and New Media. This new media has opened new platforms and communication channels for its users around the globe.

The use of Internet as a private advertisement campaign started in nineties but the advent of social media including facebook, YouTube, twitter, blogs and discussion boards has demonstrated the true strength of this medium.

Today it is no more difficult for a common person to make his views on any of the current happening wit in the country as well as around the globe. People use to discuss ranging from economic crisis 
in country to international political paradigm shifts without any censor and fear. It can be said easily that Social media has now become a new hub and platform for communication. Social media has become a new phenomenon in the political spectrum of the world. Only a decade ago television and internet were considered new media but today we are living in the age of facebook, twitters and blogs; a new social media.

Social networking has been described as the contemporary way that people interact. While that may be true, an individual's social success in the virtual world doesn't appear to carry over into the real world, according to a new study. Previous studies on how the Internet affects relationships have produced mixed findings. Some research shows that lots of social networking activity has a negative effect on social life while others suggest it enhances one's social circle. The new study, led by Thomas V. Pollet of the University of Groningen in the Netherlands, examined 117 people age 18 to 63. They filled out an extensive questionnaire about the time they spend on instant messaging and social network sites, the number of relationships they had overall and the closeness of those relationships.

Social media has got immense importance after its role in political campaign of U.S presidential elections 2008. Many of the political scholars termed these elections as "facebook election", "twitter election" and "New media elections". Facebook and You Tube were used as a tool to deliver messages and share the timings and venues of meetings and public addressees by the presidential candidates. According to many political scholars of U.S.A the biggest factor which boosted up the campaign of Barack Hussain Obama and provides him platform to communicate with his supporters and voters was the use of social media specially facebook.

Facebook also played a pivotal role in Tunisian and Egypt revolution. Protestors couldn't get proper coverage from the national TV so they used the platform of social media like facebook and twitter to not only communicate and deliver message to mainstream international media but also to gather protestors and inform them about the next place of protest.

Pakistan has a democratic parliamentary federal system of government. Although it has a democratic system of choosing public representatives but three military coups of 1958-1971, 1977-1988 and 1999-2008 haven't strengthened the democratic system of Pakistan.

Social Bakers.com is a credible research company in terms of social media research. According to which Pakistan has 6943720 active users and astonishingly $50 \%$ of the users are between the ages of 25-34. According to latest statistics of socialbakers.com among 6943720 users, $69 \%$ male and $31 \%$ females use internet.

Youth use facebook for many different purposes. A new trend on facebook is observed by the researchers that many of the facebook users share political content on facebook like pictures, videos and advertisements of a particular political party leader or Political party. According to media report now the mainstream Political parties of Pakistan have formed their social media teams whose primary duty is the image building of its political party as well as the leaders of the parties. These social media activist try to circulate the activities and manifesto of its affiliated party. They also counter the propaganda led by opponent political party's social media team. In this research researcher will try to examine and find out that can facebook be used as a powerful tool in political scenario of Pakistan.

\section{Research Question}

Whether and to what extent exposure to political content on facebook affects, Political Behavior of Students of University of Gujrat?

\section{Hypothesis}

- More the exposure to political content on facebook more is the online political participation by students.

- Intensity of exposure to political content on facebook usage is directly related to traditional political participation.

- Students would be more vigilant to cast a vote in coming elections.

- Students would be more vocal to discuss political conditions of the country with parents and friends.

\section{Facebook}

Facebook is a social networking website which was launched in 2004. Initially membership was only available for the students of Harvard College and within one month, more than half of the degree students at Harvard got themselves registered on Facebook. Like other social media website facebook provide its users a formatted page in which users use to enter his or her personal information like name, age, gender, education, place of birth, religious and political views, marital status, likings and disliking and his personal or family pictures etc. Facebook also provide services like "private messaging" system as well as public messaging system in the form of "Wall".

\section{Facebook user in Pakistan}

Pakistan has a huge chunk of population using Facebook. Pakistan has 6898720 facebook users which make Pakistan 29 in the ranking of Facebook statistics (socialbaker.com). According to social badker.com, 3.89 of total population of Pakistan use facebook. Astonishingly the largest age group is currently 18-24 with total 073368113 users followed by the users in the age $25-34$. Out of $3.89 \%$ of facebook users $69 \%$ are male and $31 \%$ female users in Pakistan. According to Pakistan Telecommunication Authority, more than 20 million Pakistanis are online, which means that the number using Facebook is only $32.86 \%$ of the total online population.

\section{Students of mass communication and CS/IT}

A Pilot study was conducted before choosing the sample from the University of Gujrat. It was found after the pilot study that students of Mass communication and CS/IT use facebook the most among other departments. They are the active users of facebook.

\section{Literature Review}

Media may influence the public not only by choosing the slant of a particular story but also choosing what to report [5-11].

Alen Gerber et al. [12] argued that Media bias may alter behavior and opinions. They added that knowledge of news events and little exposure to daily newspaper influence voting behavior as well as public opinion.

Negroponte [13] and Rash [14] were of the opinion that internet has potential of renewal of democracy. 
Gibson and Ward [15] argue that five functions are important for website if it is to be used for political purpose it includes flow of info, multimedia and interactivity, interactivity for content sharing use of hyperlinks, effective feedback.

Marta [16] says Facebook is modern and effective in statement for E-campaigning [17-20].

New media which include blogs forums and social networking sites have become a platform for political expression and discussion [21].

Wojcieszak and Mutz [22] found 53\% of youth observe political discussion in online chat rooms \& forums as compared to sites related to their habits and fan sites.

Krueger [23], Mossberger et al. [24] found that youth is a heavy consumer and user of new media.

Pew research Institute and American life project examined that $64 \%$ of youth on internet involves in online content formation and $28 \%$ have developed personal blogs [25].

Erikson; Smith; Jennings and Niemi [26-29] suggested that youth is time of significant political identity development \& this development has lasting effects.

An easy approach for any individual to share it on SNS is viewed as step toward more democratic society. Benkler, Jenkins and Salter [30-33], mention that social networking sites provide a logical sphere for voice cultivation and political citizenship formation:

Conway [34] says that political participation is indicated through electoral activities, voting and to work for political parties.

Verba et al. [35] say that working for the betterment of community and attending political protests refers to political participation

Zukin et al. [36] argues political participation involves public voice and process through which common public give views on public issues. It may include contacting official, boycotting and protestin.

Pasek [37] found that intensity of usage of social networking sites is positively associated with offline political participation.

Those who consume social networks are not likely to vote, sign a petition or boycott [38].

Tersi [39] found that information relayed through facebook increase political knowledge.

Towner et al. [40] found more exposed to facebook page effect political knowledge of candidate.

Althaus and Tewkbury [41] argues that people now prefer online newspaper when gathering political information rather that TV and hardcopy newspaper.

Smith [42] mentions that more than 50 years of youth who have right to vote use internet during election.

Skoric and Kwon [43] found that intensity of facebook usage was marginally related to political Participation they found that those who are part of any facebook political group are found interested in other forms online participation like reading political blogs.

Ashay Payne [44] found facebook did have impact on 2008 presidential elections. It was not a direct impact rather indirect in the form of awareness and info related to election use of SNS is a cheap, fast way to interact with voters with direct message.
Visser and Stolle [45] concluded that facebook has mobilization potential they say "facebook political activism is positively associated with online and offline participation". They add that "mobilization power of facebook result in a little increase in other types of political participations."

Facebook mobilization is observed in political interested groups of facebook rather than less interested individuals.

Visser and Stolle also found posting and reading political content on facebook wall of other peoples or on open wall inspires pol. activities on other places

Popkin Jermy Revolutionary crises coincide with sudden changes in the media system of society in which they occur media has greater influence on the way events disclosed in revolutionary crises situation. Popkin further said, “The press doesn't bring the revolution, but it is the one $\&$ the some with revolution process.

Popkin Jermy says French revolution is the very first example of journalistic rhetoric. He adds revolution in media affects revolution in society. Nature of Revolutions changes with the advent in media technologies and techniques.

Ghannam and Harsh say that social media especially Facebook and twitter become powerful tool to bring political change.

Joudeh found that Facebook and twitter facilitated people of Middle East to share political videos organize protest and relay their massage to masses.

Tapscott says that without Facebook and Twitter revolution couldn't happen so fast. According to Tapscott the page which was responsible of relaying information for protestors has got 100,000 friends in a week and reached to half a million in no time.

Out of 80 million population of Egypt more than 21 years had internet and more than 4.5 million were facebook users (Internet World Stats, 2011).

It was April, 2008 when first cyber-activism attempt was made through facebook page for textile workers to place a strike. This expedience leads to 2011 protest that resulted in revolution [46-48].

Fisher concluded that when an effort was made by Government of Tunisia to ban reporting form Tahrir Square, social media transformed protester in to citizen journalist [49].

Mohenad Ahmed found that public still uses traditional media as source of political information, they learn more from online political News, forums and social networking sites like facebook and twitter, additionally he says that online political news plays a significant role in increasing political knowledge, interest and participation in political activity.

According to Marzoub and Moez the timely, speed, target specific and purpose based "collective cyber consciousness" were the qualities that made Tunisian revolution successful. He adds that positive perception was noted among Tunisian facebook users towards usefulness of facebook.

Marzoub and Moez say revolution in Tunisia set off waves of continuous protest in many neighboring countries like Egypt, Morocco, Syria, Iran, Yemen and Jordan.

Moez and Marzoub found that role of facebook in revolutions like in Tunisia, Egypt and other countries proved facebook as revolutionary weapon of dignity and freedom. 
Tamara A Small in Nov 2008 wrote in magazine "Policy option" under the topic". "The Facebook effect? Online campaigning in 2008 Canadian and U.S election". He says that the role of facebook on electoral politics remain to be examined however role of internet has gained importance in both U.S and Canada.

Vitak, Zube, Smock, Ellison and Lampe found that facebook usage is positively related to online political participation while interestingly facebook usage is not related to offline/traditional political participation.

Miller wrote in New York Times blog that Obama had effective campaign on facebook than his opponent. Obama got lam likes on facebook during 2008.

A study by Harvard school of politics in 2011 revealed that $27 \%$ of youth is of the opinion that facebook and other social media websites have stronger effect that other type of advocacy

Shirky hows the strength of new age media and mobilize political support. He shows that how "Web 2.0" technology has gathered people and forces them to perform effectively as compares to traditional media.

Williams and Gulati found that "Facebook played a role in early 2008 nomination [50-58].

\section{Theoretical Framework}

\section{Uses and gratification theory}

Uses and gratification is a popular approach to examine that why people seek out specific media outlet and its content for personal gratification purpose. Theory revolves around the phenomenon in which a media consumer searches for some specific media that not only meet a given need but also enhance its social interaction, diversion and knowledge. According to Blumler and Kat'z Uses and Gratification theory, it is the user who has options to select a specific media outlet and its content for his gratification.

\section{Media system dependency theory}

The dependency theory was derived from Uses and Gratification theory. Media dependency refers to tendency of media consumer to rely and approach a particular communication media for his/her gratification.

\section{Cultivation theory}

Cultivation theory was put forward by George Gerbner and Larry Gross who were professors in University of Pennsylvania.

Cultivation theory revolves around the long term effects of Television.

\section{Methodology}

Survey research method was adopted in this research. Out of two major types of surveys : descriptive and analytical, analytical research procedure is adopted in this study in order to explore the relationship between facebook user's exposure to political content on facebook and its effect on political behavior of students of University of Gujrat.

\section{Population}

In the study universe is students, University of Gujrat.

\section{Pilot study}

A pilot study was conducted before choosing sample. During pilot study survey method was used to find out that student of which departments of University of Gujrat use facebook the most .It was found that students of CS/IT and MCM department use facebook the most.

\section{Stratified sampling}

Stratified sampling is an approach used to adequate representation of Subsamples. In present study, target sample of 120 was stratified on the basis of maximum facebook usage. After pilot study it was found that students of CS-IT and Mass Communication use facebook the most. So an equal number of respondent, 60, 60 were taken as sample from CS-IT and Mass Communication.

\section{Unit of analysis}

In this study unit of analysis is one questionnaire for one respondent.

\section{Variables}

\section{Independent variables}

- Exposure to political content on Facebook

- Literal participation in politics related activities.

\section{Dependent variables}

Political Behavior of UOG students.

\section{Framing the questioner}

Each question was directly related to questionnaire's objectives.

- How much time users spend with Facebook?

-What kind of content is mostly shared on Facebook by users?

- What kind of attitude change come after exposure to political content on Facebook?

- How political perception of users change after exposing to political content on Facebook?

- What kind of behavior change is observed in the students after exposure to political content on facebook?

\section{Data presentation}

Data is presented in Univariate frequency in shape of graphics and tables along with interpretation to make it clear and understandable. Collected data was entered and interpreted by SPSS. The Tables 1-17 and Figures 1-23 below show frequency and percentage of response categories. 
Citation: Zareen S, Ali A, Junjua MA (2014) Usage of Social Networking Sites: Interpersonal Communication Motives of Youth. Arts Social Sci J

\begin{tabular}{|l|l|l|l|}
\hline & & Frequency & Percent \\
\hline \multirow{5}{*}{ Valid } & Daily & 59 & 49.2 \\
\cline { 2 - 4 } & On alternate days & 26 & 21.7 \\
\cline { 2 - 4 } & Once in a week & 27 & 22.5 \\
\cline { 2 - 5 } & Once in a month & 8 & 6.7 \\
\cline { 2 - 4 } & Total & 120 & 100 \\
\hline
\end{tabular}

Table 1: Frequency of usage of facebook.

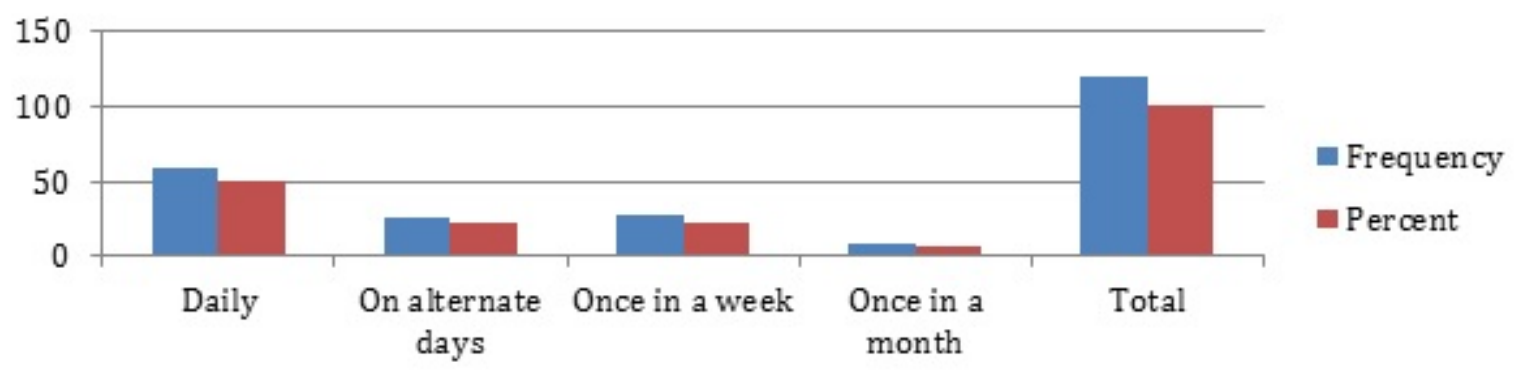

Figure 1: Presentation of frequency of Usage of facebook.

\begin{tabular}{|l|l|l|l|}
\hline & & Frequency & Percent \\
\hline \multirow{5}{*}{ Valid } & Less than 5 hours & 43 & 35.8 \\
\cline { 2 - 5 } & More than 5 hours & 41 & 34.2 \\
\cline { 2 - 4 } & Less than 20 hours & 25 & 20.8 \\
\cline { 2 - 4 } & More than 20 hours & 11 & 9.2 \\
\cline { 2 - 4 } & Total & 120 & 100 \\
\hline
\end{tabular}

Table 2: Time spent on facebook.

\begin{tabular}{|l|l|l|l|}
\hline & & Frequency & Percent \\
\hline \multirow{4}{*}{ Valid } & Information & 33 & 27.5 \\
\cline { 2 - 4 } & Entertainment & 40 & 33.3 \\
\cline { 2 - 4 } & Sharing personal content & 33 & 27.5 \\
\cline { 2 - 4 } & Business Purpose & 2 & 1.7 \\
\cline { 2 - 4 } & Networking & 12 & 10 \\
\cline { 2 - 4 } & Total & 120 & 100 \\
\hline
\end{tabular}

Table 3: Purpose of using facebook.

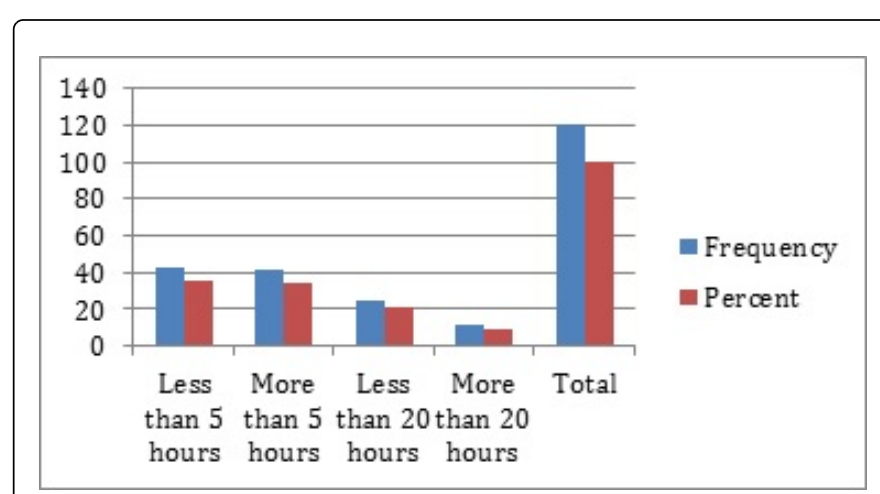

Figure 2: Presentation of time spent on facebook. 
Citation: Zareen S, Ali A, Junjua MA (2014) Usage of Social Networking Sites: Interpersonal Communication Motives of Youth. Arts Social Sci J

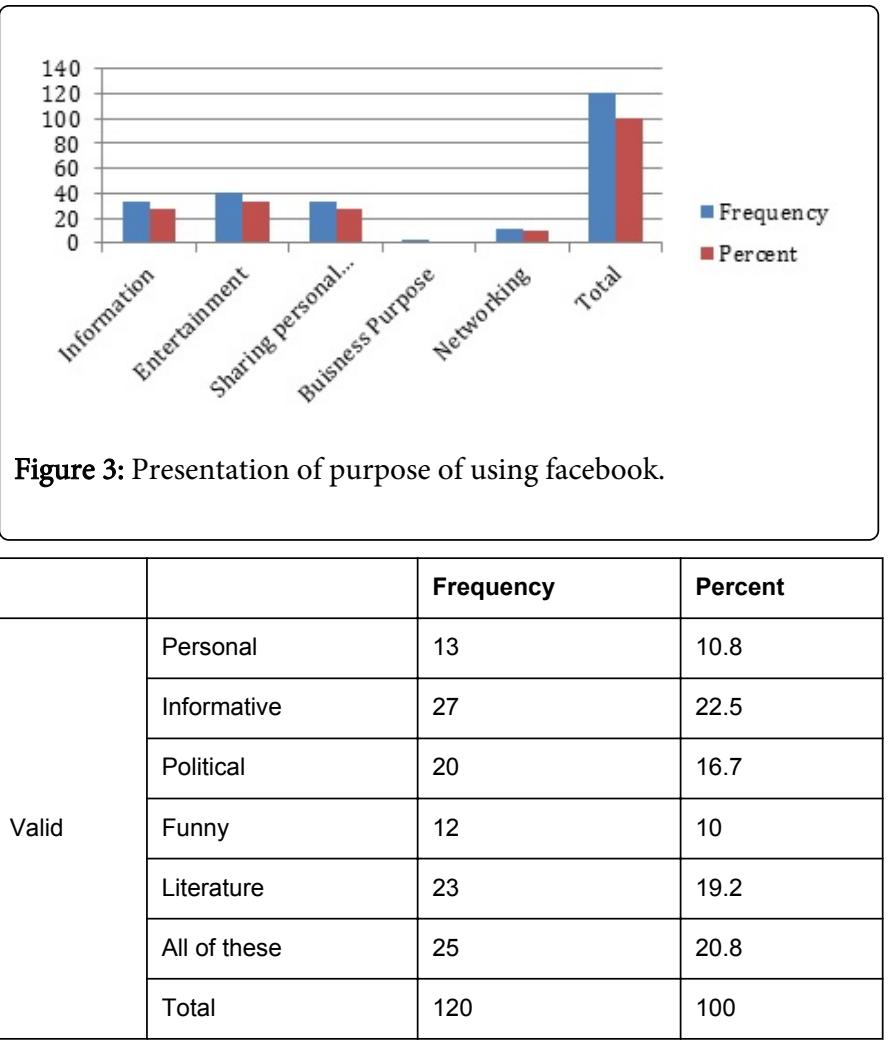

Table 4: Kind of Content shared on facebook.

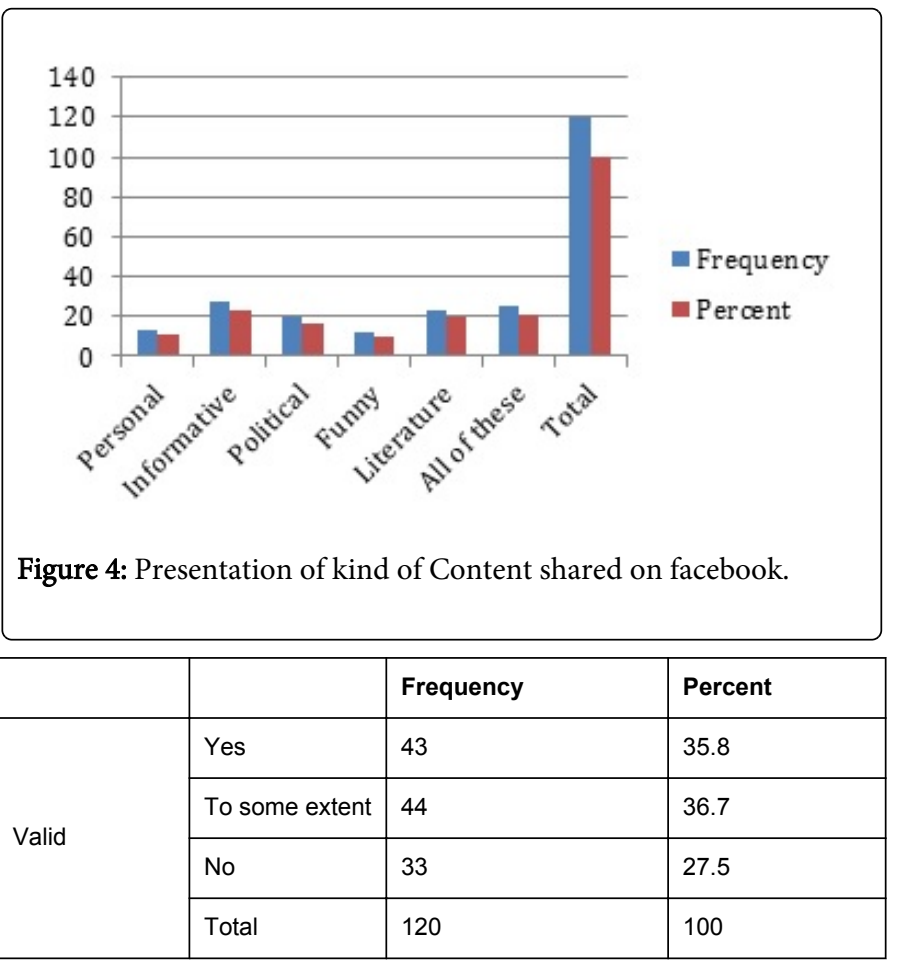

Table 5: Do you share political content on facebook?

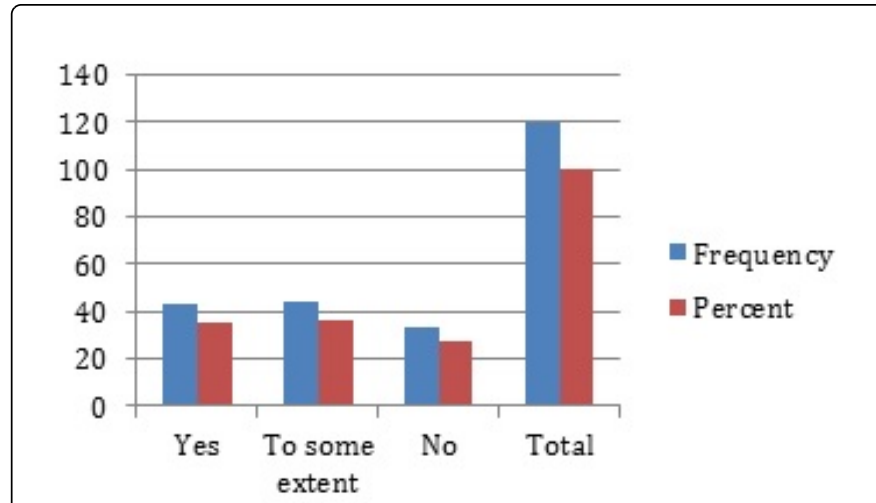

Figure 5: Do you share political content on facebook.

\begin{tabular}{|c|c|c|c|}
\hline & & Frequency & Percent \\
\hline \multirow{5}{*}{ Valid } & For political updates & 20 & 16.7 \\
\hline & $\begin{array}{l}\text { To share your } \\
\text { political ideas }\end{array}$ & 41 & 34.2 \\
\hline & $\begin{array}{ll}\text { To inform } & \text { other } \\
\text { people } & \text { about } \\
\text { personal } & \text { political } \\
\text { affiliation } & \end{array}$ & 27 & 22.5 \\
\hline & $\begin{array}{l}\text { To create political } \\
\text { awareness among } \\
\text { other students }\end{array}$ & 32 & 26.7 \\
\hline & Total & 120 & 100 \\
\hline
\end{tabular}

Table 6: Reasons of sharing political content on facebook.

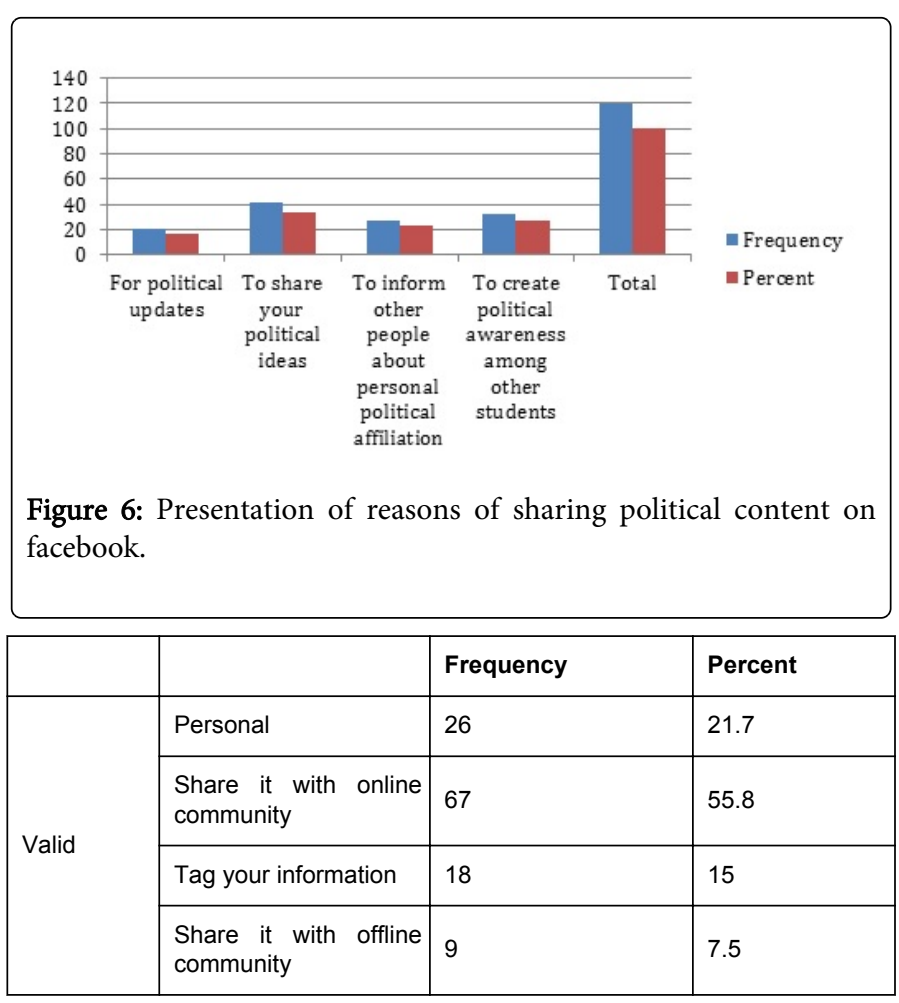


Citation: Zareen S, Ali A, Junjua MA (2014) Usage of Social Networking Sites: Interpersonal Communication Motives of Youth. Arts Social Sci J

\begin{tabular}{|l|l|l|l|}
\hline Total & 120 & 100 \\
\hline
\end{tabular}

Table 7: How do you keep political information which you get from facebook?

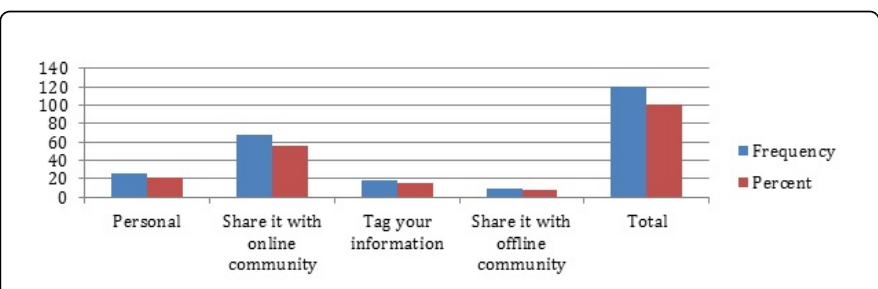

Figure 7: Presentation of the way that how people keep political information got from facebook.

\begin{tabular}{|l|l|l|l|}
\hline & & Frequency & Percent \\
\hline \multirow{7}{*}{ Valid } & $\begin{array}{l}\text { Joining political } \\
\text { forums }\end{array}$ & 15 & 12.5 \\
\cline { 2 - 4 } & $\begin{array}{l}\text { Watching political } \\
\text { talk shows on TV }\end{array}$ & 71 & 59.2 \\
\cline { 2 - 4 } & $\begin{array}{l}\text { Following political } \\
\text { news on newspaper }\end{array}$ & 17 & 14.2 \\
\cline { 2 - 4 } & $\begin{array}{l}\text { Following online } \\
\text { newspaper for } \\
\text { political news } \quad 17\end{array}$ & 14.2 \\
\cline { 2 - 4 } & Total & 120 & 100 \\
\hline
\end{tabular}

Table 8: Kind of attitude change after exposure to political content on facebook.

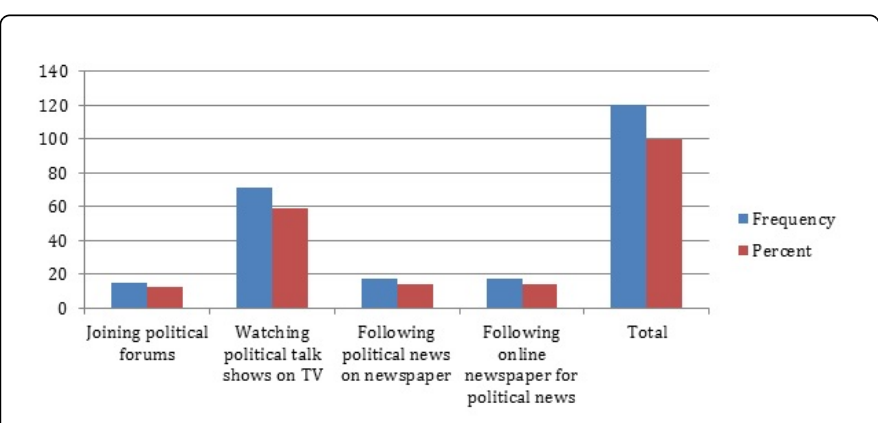

Figure 8: Presentation of kind of attitude change after exposure to political content on facebook.

\begin{tabular}{|l|l|l|l|}
\hline \multirow{4}{*}{ Valid } & & Frequency & Percent \\
\hline \multirow{4}{*}{} & Yes & 44 & 36.7 \\
\cline { 2 - 4 } & To some extent & 57 & 47.5 \\
\cline { 2 - 4 } & No & 19 & 15.8 \\
\cline { 2 - 4 } & Total & 120 & 100 \\
\hline
\end{tabular}

Table 9: Do you share your political information with your family?

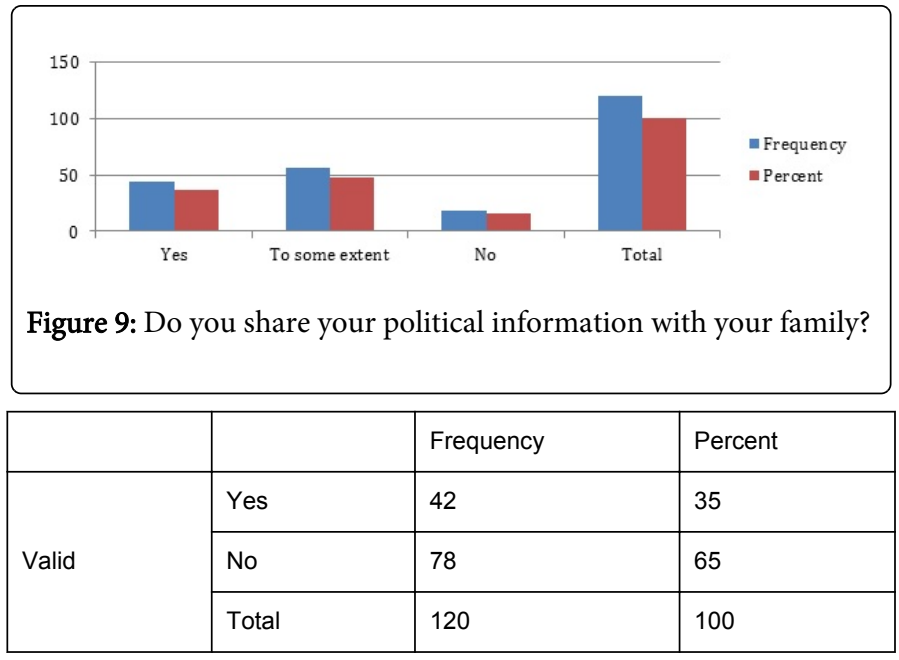

Table 10: Do you follow any political party's event on facebook?

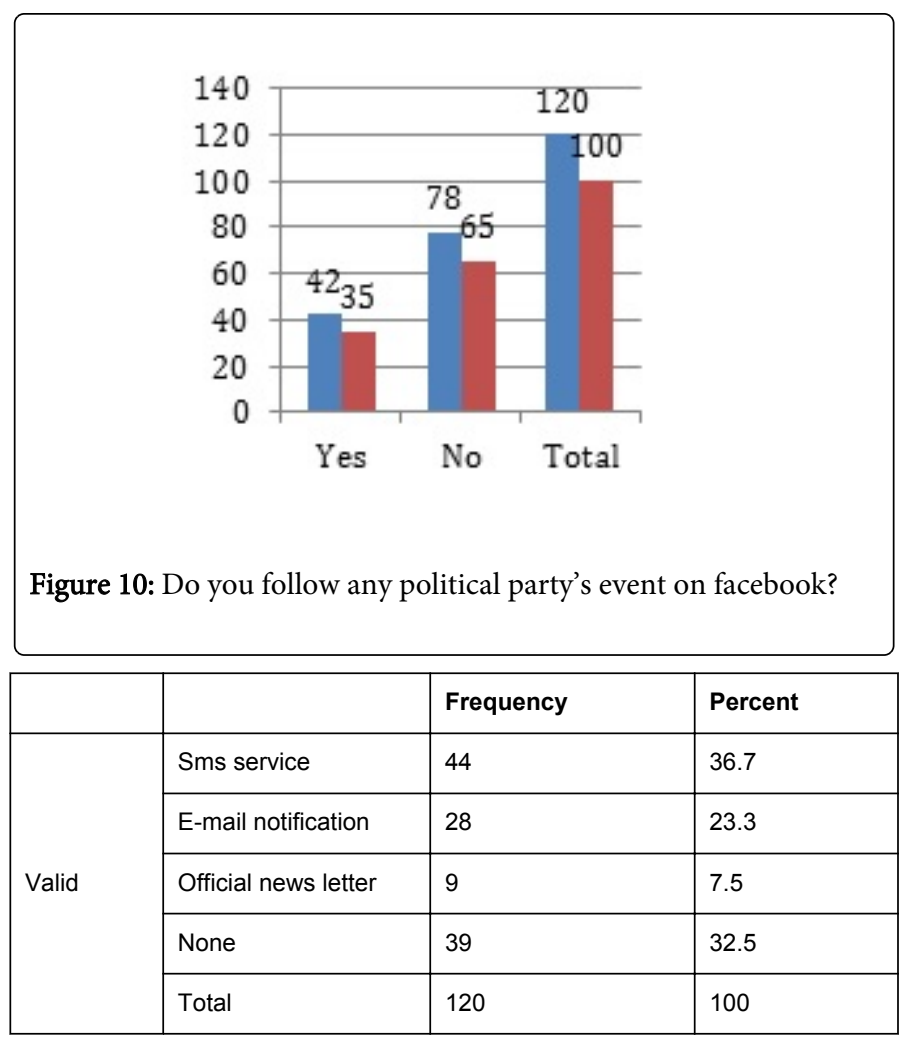

Table 11: Subscriptions to any political parties in following ways. 
Citation: Zareen S, Ali A, Junjua MA (2014) Usage of Social Networking Sites: Interpersonal Communication Motives of Youth. Arts Social Sci J

\begin{tabular}{|c|c|c|c|}
\hline $\begin{array}{r}140 \\
120 \\
100 \\
80 \\
60 \\
40 \\
20 \\
0\end{array}$ & & 1 & $\begin{array}{l}\text { - Frequency } \\
\text { - Percent }\end{array}$ \\
\hline \multicolumn{4}{|c|}{$\begin{array}{l}\text { Figure 11: Presentation of subscriptions of political party's } \\
\text { campaign based services. }\end{array}$} \\
\hline & & Frequency & Percent \\
\hline \multirow{7}{*}{ Valid } & Meeting & 13 & 10.8 \\
\hline & Rally & 27 & 22.5 \\
\hline & Procession & 7 & 5.8 \\
\hline & Strike & 13 & 10.8 \\
\hline & Fund raising & 15 & 12.5 \\
\hline & None & 45 & 37.5 \\
\hline & Total & 120 & 100 \\
\hline
\end{tabular}

Table 12: Do you attend any political party's?

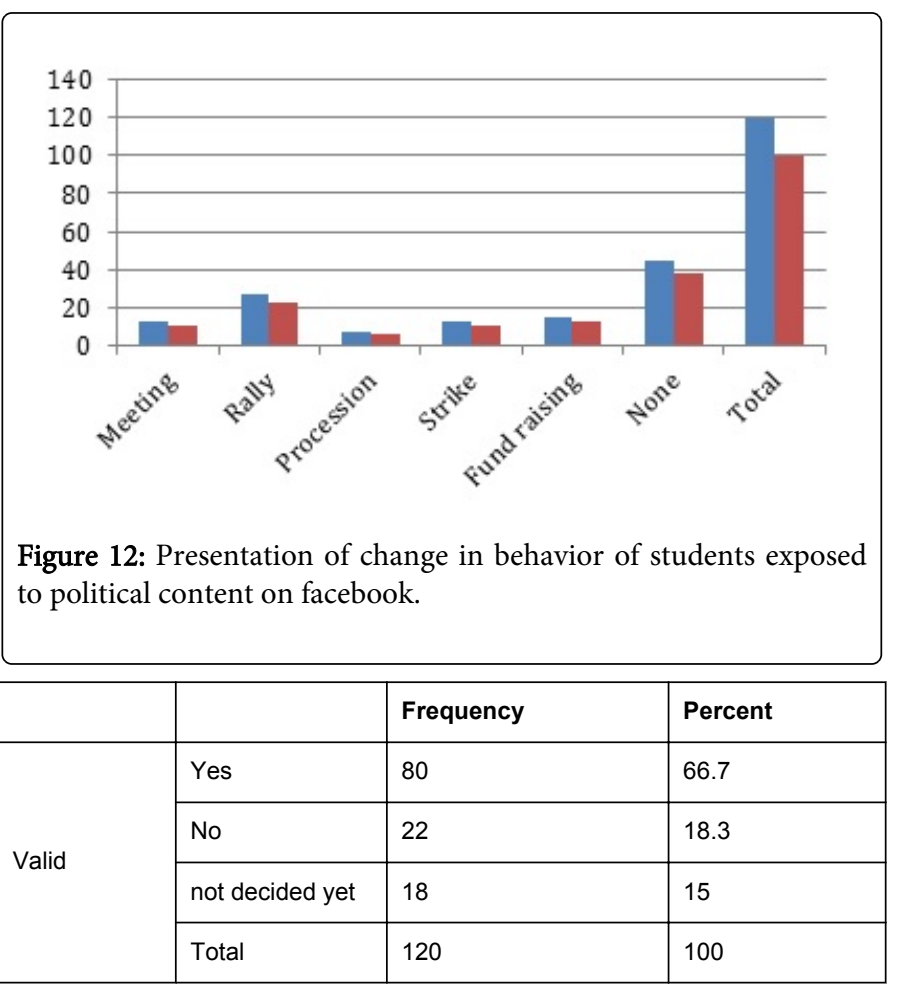

Table 13: Willingness to vote in next election?

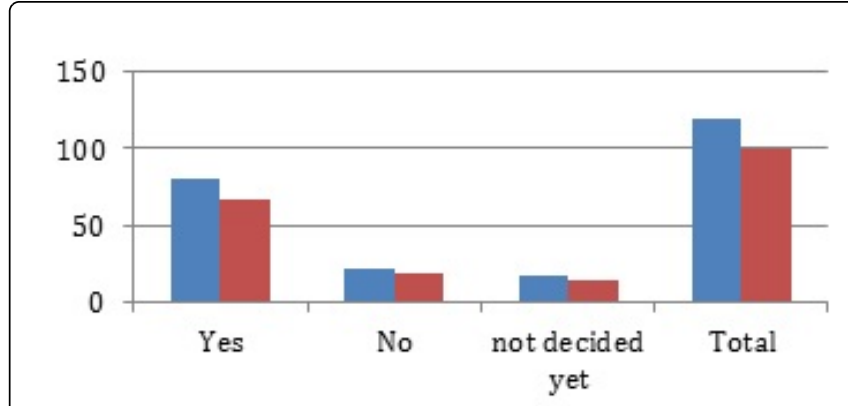

Figure 13: Presentation of willingness to vote in next election.

\begin{tabular}{|l|l|l|l|}
\hline & Frequency & Percent \\
\hline \multirow{7}{*}{ Valid } & Lack of awareness & 29 & 24.2 \\
\cline { 2 - 4 } & $\begin{array}{l}\text { Political candidates } \\
\text { are corrupt }\end{array}$ & 37 & 30.8 \\
\cline { 2 - 4 } & $\begin{array}{l}\text { Because of the } \\
\text { thought that change } \\
\text { can't be brought } \\
\text { through elections }\end{array}$ & 24 & 20 \\
\cline { 2 - 5 } is just & $\begin{array}{l}\text { Voting istage of time } \\
\text { wast }\end{array}$ & 8 & 6.7 \\
\cline { 2 - 4 } & $\begin{array}{l}\text { Political system is } \\
\text { corrupt }\end{array}$ & 22 & 18.3 \\
\cline { 2 - 4 } & Total & 120 & 100 \\
\hline
\end{tabular}

Table 14: Reasons of not casting vote.

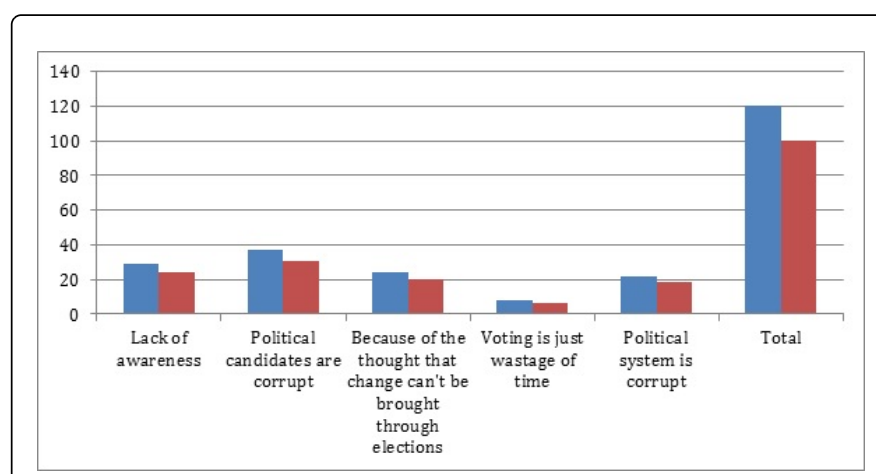

Figure 14: Presentation of reasons of not casting vote.

\begin{tabular}{|l|l|l|l|}
\hline \multirow{4}{*}{ Valid } & & Frequency & Percent \\
\hline \multirow{3}{*}{} & Yes off course & 33 & 27.5 \\
\cline { 2 - 5 } & to some extent & 57 & 47.5 \\
\cline { 2 - 5 } & Not at all & 30 & 25 \\
\cline { 2 - 4 } & Total & 120 & 100 \\
\hline
\end{tabular}

Table 15: Effect of facebook on traditional political affiliation. 
Citation: Zareen S, Ali A, Junjua MA (2014) Usage of Social Networking Sites: Interpersonal Communication Motives of Youth. Arts Social Sci J

Page 9 of 13

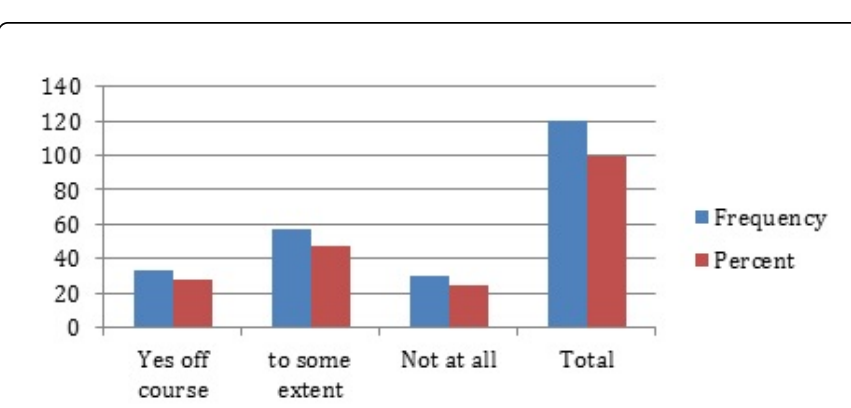

Figure 15: Presentation of effect of facebook on traditional political affiliation.

\begin{tabular}{|l|l|l|l|}
\hline \multirow{4}{*}{ Valid } & & Frequency & Percent \\
\hline \multirow{4}{*}{} & Yes & 57 & 47.5 \\
\cline { 2 - 4 } & To some extent & 52 & 43.3 \\
\cline { 2 - 4 } & No & 11 & 9.2 \\
\cline { 2 - 4 } & Total & 120 & 100 \\
\hline
\end{tabular}

Table 16: Political content sharing on facebook can bring positive and concrete change in Pakistani Political System?

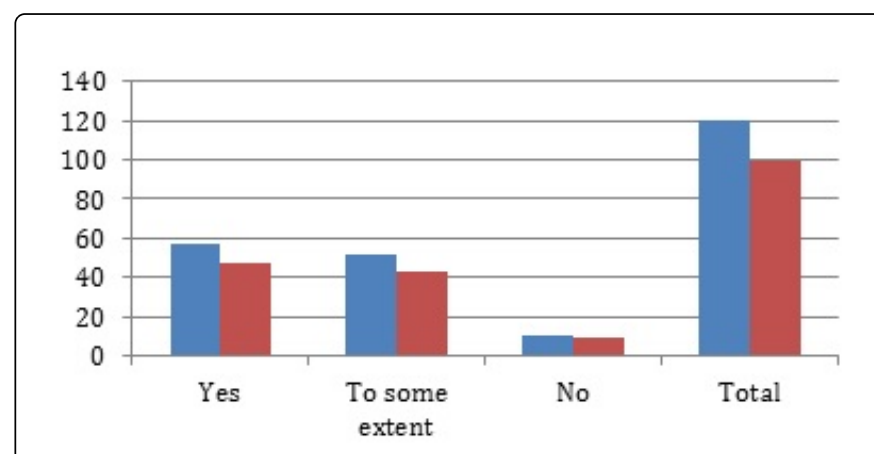

Figure 16: Political content sharing on facebook can bring positive and concrete change in Pakistani Political System.

\begin{tabular}{|c|c|c|c|c|c|c|c|}
\hline & & \multicolumn{5}{|c|}{$\begin{array}{l}\text { Do you share political content on } \\
\text { facebook }\end{array}$} & \multirow[t]{2}{*}{ Total } \\
\hline & & Yes & $\begin{array}{l}\text { To } \\
\text { exte }\end{array}$ & some & No & & \\
\hline \multirow{2}{*}{$\begin{array}{l}\text { Department of } \\
\text { respondents }\end{array}$} & MCM & 21 & \multicolumn{2}{|l|}{22} & 17 & & 60 \\
\hline & CS-IT & 22 & 22 & 16 & & 60 & \\
\hline \multicolumn{2}{|l|}{ Total } & 43 & \multicolumn{2}{|l|}{44} & \multicolumn{2}{|c|}{33} & 120 \\
\hline
\end{tabular}

Department of respondents * Do you think sharing political content on facebook Cross tabulation

\begin{tabular}{|c|c|c|c|c|c|}
\hline & & \multicolumn{3}{|c|}{$\begin{array}{l}\text { Do you think sharing political content on } \\
\text { facebook }\end{array}$} & \multirow[t]{2}{*}{ Total } \\
\hline & & $\begin{array}{l}\text { Should be } \\
\text { encouraged }\end{array}$ & $\begin{array}{l}\text { Should be } \\
\text { discouraged }\end{array}$ & $\begin{array}{l}\text { It doesn't } \\
\text { matter }\end{array}$ & \\
\hline
\end{tabular}

\begin{tabular}{|c|c|c|c|c|c|c|c|c|}
\hline & & & & \multicolumn{2}{|c|}{$\begin{array}{l}\text { because it may } \\
\text { misguide }\end{array}$} & & & \multirow{2}{*}{$\begin{array}{l}\text { Depart } \\
\text { ment } \\
\text { of } \\
\text { respon } \\
\text { dents }\end{array}$} \\
\hline CS-IT & \multicolumn{2}{|l|}{31} & \multicolumn{2}{|l|}{8} & \multicolumn{2}{|l|}{21} & $\begin{array}{l}6 \\
0\end{array}$ & \\
\hline Total & & 63 & & 17 & & 40 & & 120 \\
\hline
\end{tabular}

Table 17: Department of respondents and sharing of Political Content.

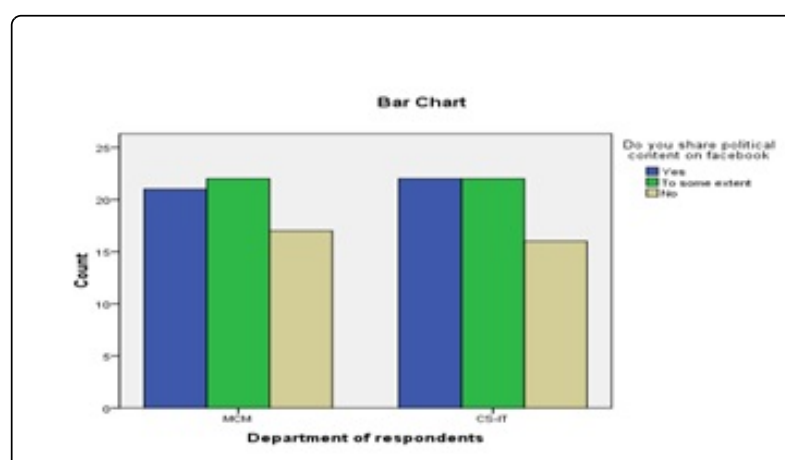

Figure 17: Representation of department of respondents and sharing of Political Content.

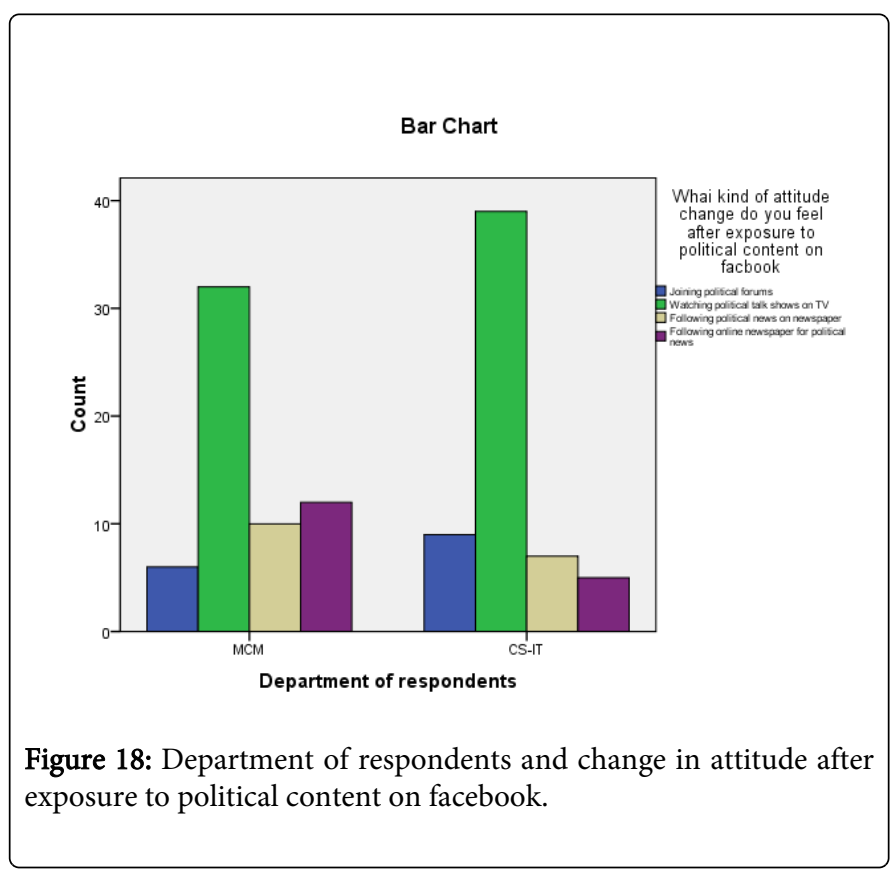




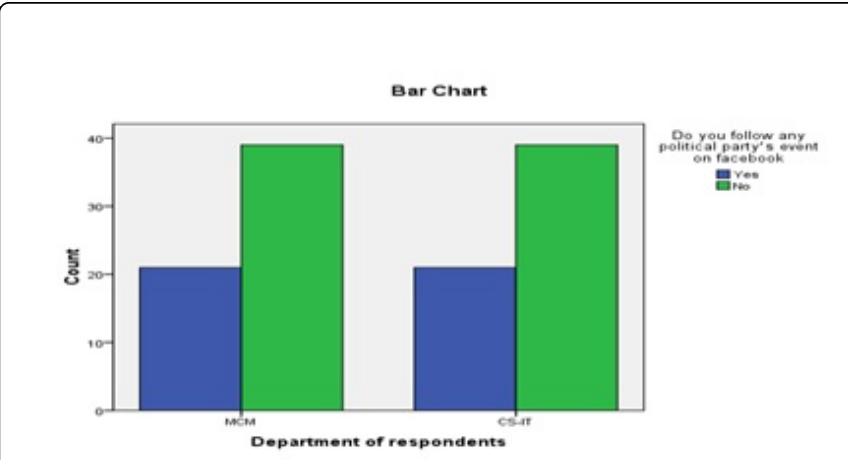

Figure 19: Department of respondents and following of Online Political Party's events on facebook.
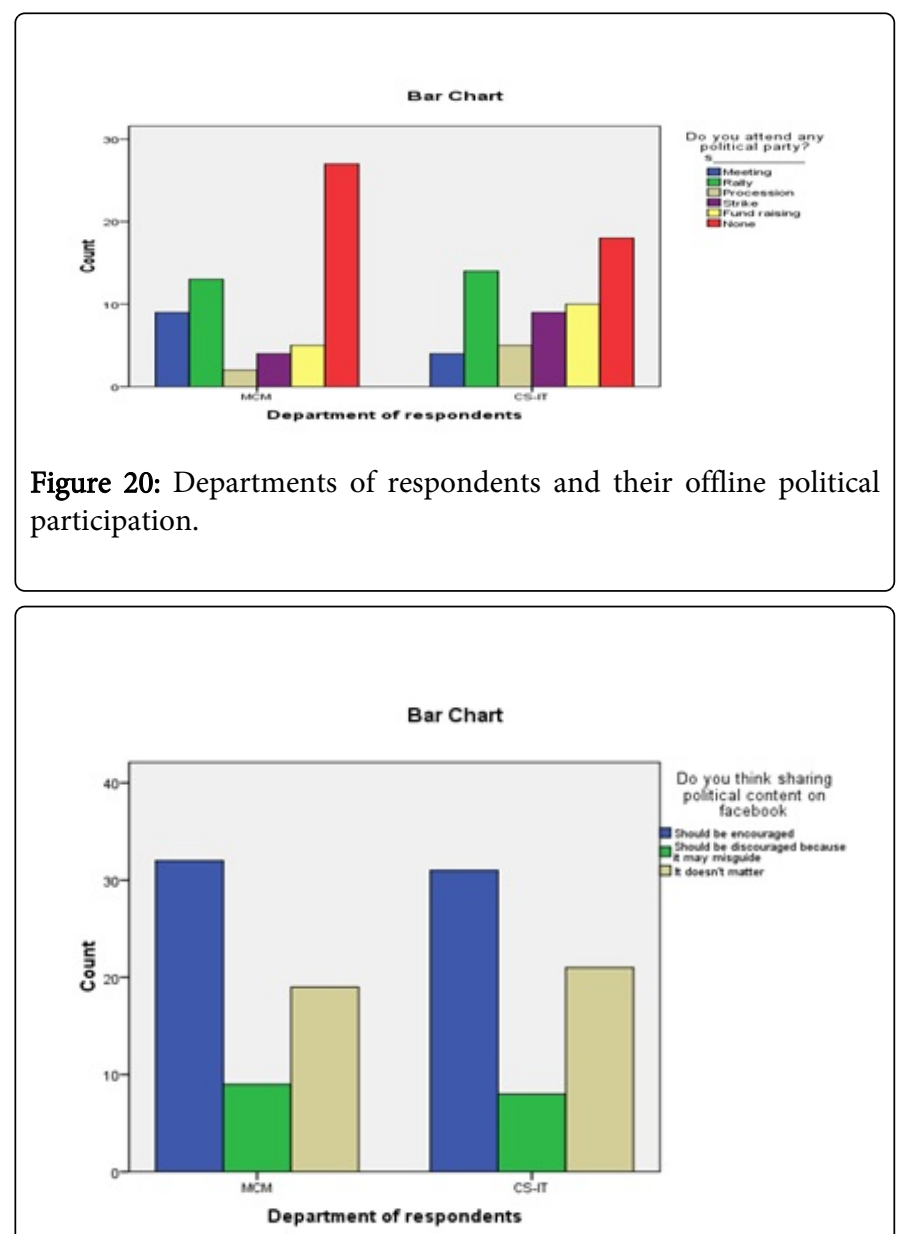

Figure 21: Department of respondents and their perception regarding sharing of political content on facebook.

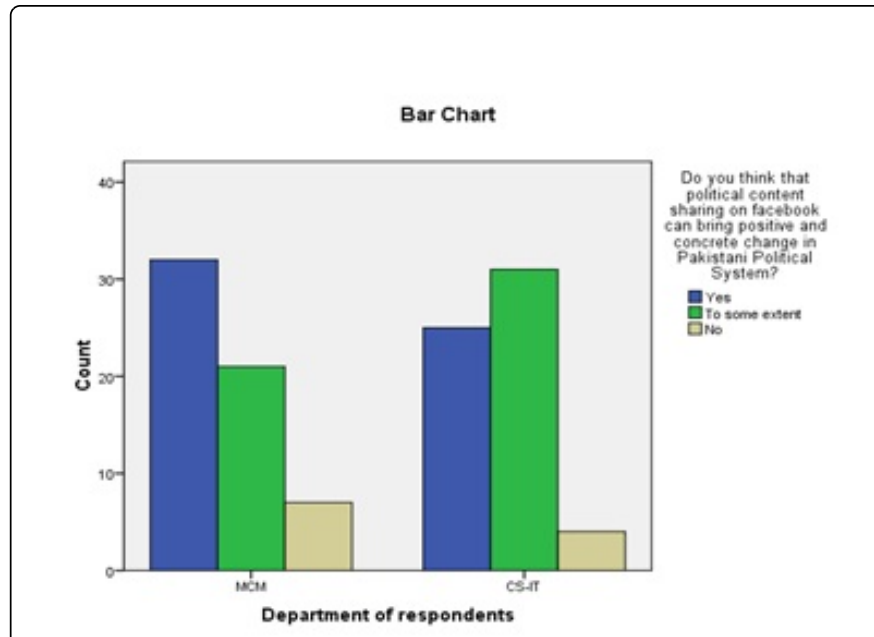

Figure 22: Department of respondents and perception about productivity of facebook in changing political system in Pakistan.

\section{Representation Discussion on Results}

Study reveals that sharing political content on facebook isn't the priority of many of the students. However $16 \%$ students share political content on facebook. Majority of student share either personal information, literary and funny content on facebook. $16 \%$ of students who share political content hold the view that they do this to share their own political ideas. $13 \%$ believe that their consent is to inform other people about their political affiliations. Sharing political information got from facebook with online community is the practice of almost $67 \%$ of students of University of Gujrat. They share it with their online friends and groups while only $26 \%$ keep that information personal.

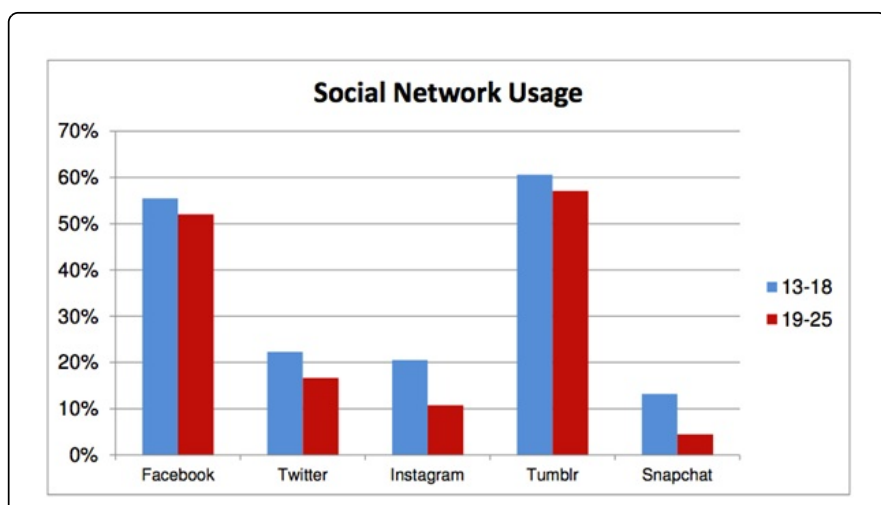

Figure 23: Social networking usage 2014.

Study reveals a considerable change in the attitude of students who are exposed to political content on facebook. Wide majority of $71 \%$ students started watching political talk shows on television. Nowadays political talk shows have gained much popularity in political arena of the country. A nearly every current issue and event of the day is discussed on talk shows on that night in two time slots 8:00 pm to 9:00 pm and 10:00 pm to 11:00 pm. 
Proportion of joining political forums on internet after exposure to political content is very low up to $15 \%$ only. The proportion of Computer Science students is more in terms of joining political forums on internet. This is because students of Computer Science and Information Technology have more exposure to internet because of its relevancy with their field.

Study shows that most of the students, almost $56 \%$ are exposed to political content on facebook or who share such type of content, don't frequently discuss it with their family members. They either discuss on important updates or if something happened unusual. Otherwise their communication remains strictly associated with their online community.

First hypothesis of the study was "more the exposure to political content on facebook more is the online political participation". It has been empirically rejected. Students who are not heavy contributors and consumers of political content facebook are not active regarding online political participation. Students who occasionally share political content on facebook are $18 \%$ which are somehow vibrant in terms of online political participation. While clear majority of $78 \%$ don't participate in any online political activity. Results suggest that contributors of political content on facebook don't have interest in any online political event or activity. They believe that this is a useless activity.

Various internet as well as telecom network based services are provided by the political parties for the people, free official newsletters, emails, and social media updates etc. Our study reveals that $44 \%$ of students, who share political content on facebook, have subscribed to sms service of particular party, for updates. Sms service has become a new phenomenon in political campaign in Pakistan. Through promotional sms political parties let the voters and supporters know about the activities of political leaders, gatherings of political candidates and party's stance on different issues on National and International level.

A vast majority of $57 \%$ believe that facebook has affected their traditional political affiliation up to some extent. This is the statement of the students who use facebook on daily basis. A percentage of 14 strongly agreed that facebook has affected their traditional political affiliation. It shows that majority of our respondents are of the view that facebook has strength to mould people's perception in some direction. No matter students share political content on facebook or not, they consider facebook as a factor to influence one's action.

Second hypothesis was, "intensity of facebook usage is directly related to offline political participation". Hypothesis is empirically approved, as almost $55 \%$ of the students who are exposed to political content on facebook are involved in offline political activities. $25 \%$ of them participate in rallies, $23 \%$ of the students don't participate in any form of traditional political campaign. It shows that exposure to Facebook's political content is directly related to offline political activities.

$57 \%$ of the students among the sample are of the opinion that sharing political content on facebook can bring positive and concrete change in Pakistan. However 52\% partially agree with this statement while only $11 \%$ believe that such activity can't bring change. It indicates that most of the students have clear perception and belief that facebook can act as a catalyst to bring change in political scenario of Pakistan.
$52.5 \%$ of respondents believe that sharing of political content on facebook should be encouraged while $33 \%$ believe that political content on facebook don't make any difference. $47.5 \%$ of students don't have any friend or family member who belongs to any political party.

Interestingly $66.7 \%$ students are willing to vote in next elections and to become a part of electoral system of Pakistan and clear cut majority of $78.3 \%$ believe that they would cast vote with their own personal decision instead of traditional voting pattern or family motivated polling.

Lack of awareness and corrupt background of the political leaders are the two reasons because of which a total of $55 \%$ of students believe that people don't cast vote. Only $6.7 \%$ believe that voting is just wastage of time. Confidence of students on political candidates and political system is very low. They believe that lack of education and awareness is one of the main reasons because of which voting turnout in elections are very low.

Third hypothesis of the study was, "exposure to political content on facebook shows the difference between male and female students". This hypothesis is empirically proven, as the study finds that $67 \%$ of male respondents showed change in their attitude after exposure to political content facebook, $33 \%$ of them started watching political talk shows on TV while $12 \%$ and $11 \%$ of male students started following online newspapers as well as printed newspaper for political content, respectively. In contrast to that $53 \%$ of female respondents found change in their attitude after exposure to political content on facebook. Astonishingly $38 \%$ of them started watching political talk shows followed by $6 \%$ who started reading political news on facebook. Study reveals that students who are moderate contributors and consumers of political content on facebook are more vibrant in terms of offline political participation.

Male students are more vibrant in terms of both online and offline political participation as compared to female students of CS-IT and MCM department. A slight difference of opinion is observed in this study about the perception of students of both departments regarding productivity of political content on facebook. 57\% of CS-IT students believe that sharing political content on facebook can bring positive and concrete change in Pakistan, followed by $56 \%$ of MCM students.

$14 \%$ of CS-IT students are not willing to cast vote in next elections because of corruption of political candidates and corrupt political system. $44 \%$ of MCM students are willing to vote in next elections while only $8 \%$ say that they won't cast vote in next elections. However majority of MCM students believe that political candidates are undoubtedly corrupt. Students of Urban area use facebook more than students from sub Urban and Rural areas. Moreover 56\% students believe that facebook has affected their traditional political affiliation.

Another phenomenon was hypothesized as "Students would be more vigilant to cast vote in coming elections". This hypothesis is empirically proven. $66.7 \%$ students showed their willingness to vote in next general elections. They consider this act as significant step to change the political scene of Pakistan. Non availability of National ID card was one of the main reasons of not casting vote in last general elections. This also shows their improved awareness level regarding political condition of Pakistan. It was also hypothesized that "Students would be more vocal to discuss political conditions of the country with parents and friends". It is empirically proven. $84.3 \%$ students share political condition and political ideas with their families. This shows their concerns about the political situation of Pakistan. It is found that 
students of CS/IT are more vibrant in terms of sharing political content on facebook. Comparative to Mass Comm. students, more than $50 \%$ students of CS/IT share political content on facebook. This shows their interest in Pakistani politics. However students of both departments have equal proportion of online political participation, $22 \%$ each.

In case of offline political participation in political events and activities, students of CS/IT are more vibrant and interested. Almost $47 \%$ students of CS/IT participate in different offline political activities ranging from rallies to fund raising. The role of social media in bringing political awareness among students of different academic programs.

\section{References}

1. Hamilton S (2009) Use of social media in Presidential campaigns: Do social media have and effect on political behavior of voters aged 18-24.Department of politics and International relations. Roger Williams University, USA.

2. Baumgartner JC, Morris JS (2010) My Face Tube Politics. Social Networking Web sites and political engagement of young adults. Social Science Computer Rev 28: 24-44.

3. Budak A (2010) Facebook, Twitter and Barack Obama: New media and 2008 Presidential elections. Faculty of Graduate school of Arts and Sciences, Georgetown University, USA.

4. Burki, Javed S (2011) Tunisia's Ripple Effects. Dawn. (n.d).

5. Can change really take place in presence of Hosni Mubarak? [Editorial]. (2011, February 1).Washington Post. Chomsky, N. (2011, February2) .Democracy now. (Retrieved 17 September, 2012)

6. Cohen, Kahne J (2009) New media and youth political Action. MacArthur research network.

7. Dalacoura K (2012) The 2011 upspring in the Arab Middle East: Political change and geopolitical implications. The Royal Institute of International Affairs.

8. Denton J (2009) The 2008 Presidential Campaign: A Communication Perspective (Communication, Media, and Politics). (Retrieved 23 September, 2012).

9. Dionne EJ (2011) Turmoil of Egypt as a lesson in humility. Washington Post, USA.

10. Emruli S, Baca M (2011) Internet and political communicationMacedonian case. Faculty of organization and informatics. University of Zagreb, USA.

11. Friedman LT (2011) Up with Egypt. The New York Times, USA.

12. Ghonim W (2012) Revolution 2.0: the Power of the People Is Greater Than the People in Power: a Memoir. (Retrieved 23 September, 2012).

13. Glenn G, Sparke (2010) Media effects research: A basic review. Wards worth, Boston. USA.

14. Goodman DS (2011) Social Media: The use of facebook and twitter to impact political unrest in the Middle East through the power of collaboration. The faculty of Journalism Department. California polytechnic University, San Luis Obispo, USA.

15. Herman ES, Chomisky N (2000) Manufacturing consent: The political economy of mass media. NewYork: Panteon Books, USA.

16. Iskander E (2011) Connecting the national and virtual: Can facebook activism remain relevant after Egypt's January 25 Upspring. London School of Economics and Political Science.

17. Krikpatric D (2010) The Facebook Effect. (Retrieved 23 September, 2012).

18. Kristof DN (2011) We are all Egyptians. The New York Times. (n.d), USA.

19. Marcheva M (2010) The real political powers of internet: Facebook, a possible new hub of European elections? University of Pantheon Assas Paris, UK.
20. Marichal J (2010) Political facebook groups: Micro activism and the digital front stage. California Lutheran University, USA.

21. Mainwaring S (2011) Re: Exactly what role did social media ply in the Egyptian revolution? Message posted to.

22. Marzouki Y, Hammoudi H (2012) The contribution of facebook to the 2011 Tunisian revolution: A cyber psychological insight.

23. McKinney (2010) Communication in the 2008 U.S. Election (Frontiers in Political Communication). (Retrieved 23 September, 2012).

24. Mc Quail D (2005) Mass Communication Theory, 3rd Edition, Vistaar Publications, New Delhi.

25. Morozov E (2009) Iran: Downside to the "Twitter Revolution". Dissent 56: $10-14$.

26. Mourtada R, Salem F (2011) Civil movements. The impact of facebook and twitter. Arab social Media Report.

27. Osama A, Samei MA (2011) The media and the making of the 2011 Egyptian Revolution. Cairo University, USA.

28. Payne A (2009) The new campaign, social networking sites in the 2008 Presidential elections. Honors College Capstone Experience. Western Kentucky University, USA.

29. Rafaeli S (1988) Interactivity: From New Media to Communication. In R. P. Hawkins, J. M. Wiemann \& S. Pingree (Eds.), Advancing Communication Science: Merging mass and interpersonal processes (pp. 110-134). Newbury Park, CA: Sage Publications, UK.

30. Raymond W, Preisis (2001) Mass media effects researcher advance through Meta Analysis, publisher: Lawrene Erlbaum Association, Tnc Mahwah, and Newberys.)

31. Said EW (1997) "The MESA debate: The scholars, the media and the Middle East”. J of Palestine Stud 16: 85-104.

32. Shaugnessy, Stadler J (2010) Media and Society.

33. Shirky C (2011) The political power of social media. Foreign Affairs. (n .d).

34. Skoric, Kwan (2011) Do Facebook and Video games promote political participation among youth. Wee Kim Wee School of communication and information, Nayang Technological University.

35. Small $\mathrm{T}$ (2009) The facebook effect? Online campaigning in the 2008 Canadian and US elections.

36. Smith K (2011) Re: Egypt's facebook revolution: Wael Ghonim Thanks the Social Network.

37. Smith NK (2011) Social media and political campaign. Tennessee Research and Creative Exchange, University of Tennessee.

38. Stromer J (2003) Diversity of political conversation on the Internet: Users' perspectives. J of Computer-Mediated Communication 8: 54-60.

39. Sulehria F (2011) Key players in Egypt's revolution. The News International. (n.d).

40. Valenzuela S, Park N, Kee F (2008) Lessons from facebook: The effect of social network sites on College student's social capital. University of Texas at Austin, USA.

41. Vissers S, Stolle D (2012) Spill-over effects between facebbok and on/ offline political participation? Evidence from a two-wave panel study. Canadian Political Science Association Annual Meeting.

42. Vitak J, Zube P, Smck A, Carr T (2010) It's complicated: Facebook user's political participation in 2008 elections. Cyber Psychology, behavior and social networking.

43. West R, Turner L (2000) Introducing Communication Theory, Mayfield Publishing Company, London, UK.

44. William P, Dhavan V, Nojin K (2005) Understanding the relationship between communication and political knowledge. Political Communication.

45. Wimmer R, Dominick J (2000) Mass Media Research: An Introduction, 6th Edition,Wadsworth Publishing Company, USA.

46. http:// www.csa.com/discoveryguides/ discovery guides-main.php (Retrieved 16 September, 2012).

47. http://www.docstoc.com/docs/36265100/final-synopsis doc (Retrieved 16 September, 2012). 
Citation: Zareen S, Ali A, Junjua MA (2014) Usage of Social Networking Sites: Interpersonal Communication Motives of Youth. Arts Social Sci J 5: 80. doi:10.4172/2151-6200.100080

Page 13 of 13

48. http://www.ecp.gov.pk (Retrieved 15 September, 2012).

49. http//www.ecp.gov.pk/voterstats/agewise.pdf (Retrieved 16 September, 2012).

50. http://www.education.com (Retrieved 16 September, 2012).

51. http://idia.library.drexel.edu/handle/1860/3408? mode=full\&submitsimple $=$ showt full + item + record (Retrieved 15 September, 2012).

52. http://jadailya.com/pages/index/612/egypts-revolution-2.0-the facebookfactor.

53. http://ndc.nic.in/uploads/editor-files/pdf/43-about.pdf (Retrieved 15 September, 2012)
54. http://oxforddictionaries.com/definition/english/media? $\quad \mathrm{Q}=$ media (Retrieved 15 September, 2012).

55. http://www.revolution.net/2009/09/22facebook-faster-politcalengagement/ (Retrieved 15 September, 2012).

56. http://www.social bakers.com/elections/?ref= left=menu/social/ (Retrieved 15 September, 2012).

57. http://www.social bakers.com/facebook statistics/Pakistan/ (Retrieved 15 September, 2012).

58. http://ribune.com.pk/story 330906/over-6-million-Pakistan-onfacebook/ (Retrieved 15 September, 2012). 